\title{
Se otorga el IV Premio de Teatro George Woodyard (2009)
}

\section{Laurietz Seda}

En esta cuarta edición se recibieron 71 obras provenientes de México, Argentina, Chile, Uruguay, Venezuela, Colombia, Cuba, Costa Rica, Perú y Estados Unidos. Luego de una deliberación sobre 8 obras seleccionadas, un destacado jurado de investigadores de la academia estadounidense integrado por Kirsten F. Nigro (University of Texas-El Paso, Texas), Adam Versenyi (University of North Carolina) y Timothy Compton (Northern Michigan University) decidió otorgar el IV Premio de Teatro George Woodyard a la obra Un drama turbio presentada bajo el seudónimo "ITA." Una vez abierto el sobre sellado la autora resultó ser la argentina Adriana Ferrari. Los tres miembros del jurado consideran que "esta obra pirandelliana capta al público desde sus primeros parlamentos cuando el trabajo de un dramaturgo se interrumpe con la corporización de uno de sus personajes." Señalan además que "es una obra de gran dramatismo y humor, con personajes fascinantes en una situación inusitada y reveladora."

Adriana Ferrari nació en Buenos Aires, Argentina el 1 de septiembre de 1976. En 1994 comenzó estudios de actuación en el taller para adolescentes de María Inés Falconi, en la Universidad Popular de Belgrano. Ha cursado cursos de dramaturgia con Mauricio Kartun y Carlos de Urquiza. En el 2007 obtiene el $1{ }^{\text {er }}$ Premio del concurso de dramaturgia organizado por el Instituto Nacional del Teatro por su texto "La casita feliz." Esa obra recibió también el Premio ATINA a la Dramaturgia por la producción 2008.

Un drama turbio comienza con Fabián, un dramaturgo, que está escribiendo una obra de teatro. Cuando se levanta para ir a buscar un té se da cuenta de que hay una mujer (Nuria) en su casa. Al comenzar a cuestionarla ella le declara que es un personaje de una de sus obras. Ante la incredulidad de Fabián aparece otro personaje (Roviroli) que también él ha creado. Ambos le piden a Fabián que termine y muestre sus obras para que de este modo 
los saque del olvido. De acuerdo a ellos, "Si no nos leen... Si nadie nos representa... ¡No somos otra cosa que un rejunte de palabras escritas sin sentido alguno!" Ante sus peticiones Fabián accede a que lean una de las obras en voz alta. Con ello, y los comentarios despectivos que hacen Nuria y Roviroli, el dramaturgo toma conciencia de que sus obras no son muy valiosas y comienza a borrarlas de su computadora. Al hacer esto los personajes van perdiendo fuerzas a la misma vez que discuten entre sí. La obra termina con Fabián escribiendo en su computadora los diálogos que ha escuchado de estos dos personajes en el momento en que desfallecen.

Un drama turbio es una obra metatextual que juega con los conceptos pirandellianos de aquellos personajes que nacen vivos y que quieren seguir viviendo. Nuria y Roviroli tienen su propio drama y quieren que éste sea visto por otros. Más que la palabra les importa la acción y que los demás sepan de su existencia por medio de la lectura o representación de su obra. Por otro lado, también se muestran los conflictos internos del escritor, sus motivaciones e inseguridades. La obra pone al descubierto la lucha entre la realidad versus la ficción, la palabra versus la acción y la inspiración versus la dedicación. Ferrari contruye una obra con mucho humor, de diálogos ágiles y personajes bien delineados.

\section{University of Connecticut}

